\title{
Microscopic Supraciliary Approach for Terminal Laminotomy for Treatment of Hydrocephalus: A Preliminary Report of Eight Cases
}

\section{Hidrosefali Tedavisinde Terminal Laminotomi için Mikroskopik Suprasiliyer Yaklaşım: Sekiz Olguda Ön Rapor}

\author{
Ali Tayebi MEYBODI, Seyed Mojtaba MIRI \\ Imam Khomeini Hospital, Department of Neurosurgery, Tebran, Islamic Republic of Iran
}

Correspondence address: Ali Tayebi MEYBODI / E-mail: tayebi_a77@yahoo.com

\begin{abstract}
AIM: Shunting and endoscopic third ventriculostomy for treatment of hydrocephalus have their own complications which make the management of such patients more difficult. We have examined the subfrontal route to fenestrate lamina terminalis in order to achieve relief of hydrocephalus in eight consecutive patients.

MATERIAL and METHODS: Eight patients with the diagnosis of hydrocephalus were chosen. A supraciliary approach to the central skull base was used to fenestrate the lamina terminalis to allow cerebrospinal fluid egress from the third ventricle to the basal cisterns.

RESULTS: Clinical and/or radiological remission of hydrocephalus symptoms were observed in all patients. No complications were encountered in this small series of patients.

CONCLUSION: Microsurgical third ventriculo-cisternostomy through a supraciliary might be a reasonable alternative to endoscopic third ventriculostomy. However, a more sample size with controlled subjects is required to draw conclusions and comparisons with other techniques of treatment of hydrocephalus.
\end{abstract}

KEYWORDS: Hydrocephalus, Endoscopy, Third ventriculostomy, Lamina terminalis, Supraciliary craniotomy

öz

AMAÇ: Hidrosefali tedavisi için şant yerleştirme ve endoskopik üçüncü ventrikülostomi komplikasyonlara neden olabilir ve bu nedenle bu tür hastaların takibi zordur. Arka arkaya sekiz hastada hidrosefali tedavisinde lamina terminalis fenestrasyonu için subfrontal yol kullanımını inceledik.

YÖNTEM ve GEREÇLER: Hidrosefali tanılı sekiz hasta seçildi. Lamina terminalis fenestrasyonu yapmak ve serebrospinal sıvının üçüncü ventrikülden bazal sisternlere geçmesini mümkün kılmak üzere santral kafatası tabanına suprasiliyer bir yaklaşım kullanıldı.

BULGULAR: Tüm hastalarda klinik ve/veya radyolojik hidrosefali belirtileri remisyonu görüldü. Bu küçük hasta serisinde komplikasyon görülmedi.

SONUÇ: Suprasiliyer yolla mikrocerrahi ile üçüncü ventrikülo-sisternostomi endoskopik üçüncü ventrikülostomiye makul bir alternatif olabilir. Ancak sonuca varmak ve diğer hidrosefali tedavisi teknikleriyle karşılaştırma yapabilmek için kontrol grubu ve daha büyük bir örnek büyüklüğü gereklidir.

ANAHTAR SÖZCÜKLER: Hidrosefali, Endoskopi, Üçüncü ventrikülostomi, Lamina terminalis, Suprasiliyer kraniyotomi

\section{INTRODUCTION}

Few dilemmas in the realm of neurosurgery are more perplexing to the neurosurgeon than hydrocephalus. Since the first documented attempt to its treatment by Hippocrates in 500 B.C. (15), hydrocephalus has been a major challenge in medicine, even lasting to date. Having a wide variety of causes, time courses, presentations and complications, it has forced contemporary neurosurgeons to select CSF diversion techniques as the most common treatment. A relatively new emerging technique (ETV) has shown promising results and is replacing the traditional shunting technique in some forms of the malady (13). In this paper, we report 8 cases of microscopic $3^{\text {rd }}$ ventriculostomy via fenestration of lamina terminalis through a small ellipsoid supraciliary craniotomy.

\section{MATERIAL and METHODS}

Eight cases of different causes and durations of hydrocephalus with a mean age of 31 year (ranging from 11 to 46 years) (Table I) underwent ellipsoid supraciliary craniotomy (Figure 1) to reach the lamina terminalis. Patients with recent hemorrhage 
Table I: List of Patients Undergone MTV in Current Series

\begin{tabular}{|c|c|c|c|}
\hline Number & Age(year)/Sex & Primary Diagnosis & Clinical Picture \\
\hline 1 & $11 / \mathrm{M}$ & Pineal Tumor & Persistent hydrocephalus after tumor removal \\
\hline 2 & $32 / F$ & Choroid plexus papilloma of the $4^{\text {th }}$ ventricle & $\begin{array}{l}\text { Shunted } 10 \text { years ago, Hydrocephalus due to } \\
\text { shunt malfunction }\end{array}$ \\
\hline 3 & $22 / \mathrm{M}$ & Aqueduct stenosis & Three ventricular Hydrocephalus \\
\hline 4 & $26 / M$ & Aqueduct stenosis & Three ventricular Hydrocephalus \\
\hline 5 & $36 / M$ & Chiari I malformation & $\begin{array}{l}\text { Ventriculomegaly, cervicothoracic } \\
\text { syringomyelia causing headache and left hand } \\
\text { and leg paresthesia }\end{array}$ \\
\hline 6 & $45 / F$ & Subarachnoid hemorrhage & Persistent hydrocephalus \\
\hline 7 & $46 / \mathrm{F}$ & $4^{\text {th }}$ ventricular ependymoma & $\begin{array}{l}\text { Persistent hydrocephalus after } \\
\text { tumor removal }\end{array}$ \\
\hline 8 & $21 / F$ & $\begin{array}{l}\text { Posterior fossa hemorrhage due to cavernoma } \\
\text { of the cerebellar peduncle }\end{array}$ & $\begin{array}{l}\text { Lengthy ventricular drainage necessary for } \\
\text { treatment of hydrocephalus }\end{array}$ \\
\hline
\end{tabular}

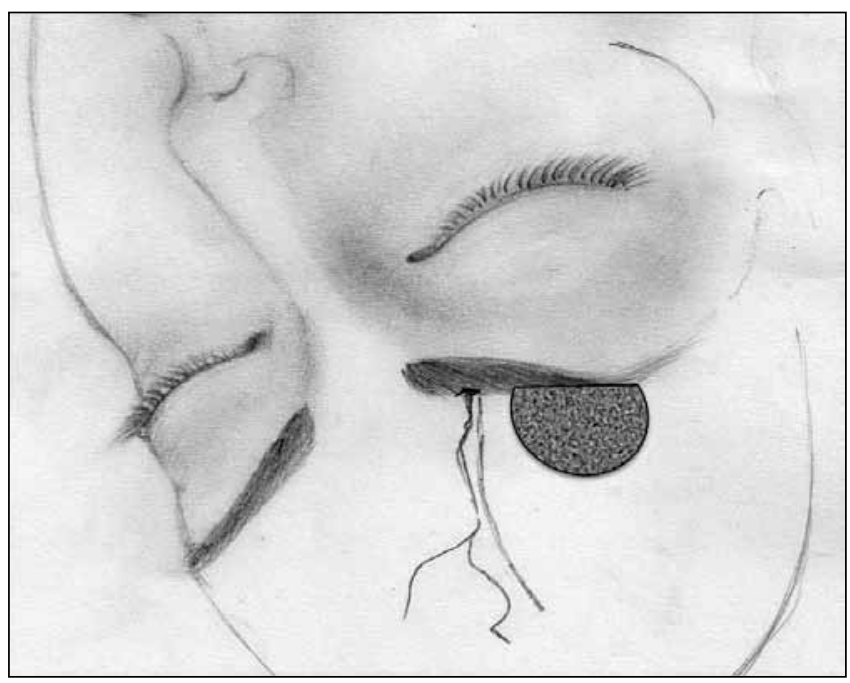

Figure 1. Schematic depiction of the extent of right supraciliary ellipsoid craniotomy (hazed area).

or massive brain edema, which would possibly get worse by direct surgical manipulation, were not designated for this approach and underwent routine shunting procedure.

\section{Technique}

The patient is positioned supine with the head being 20 degrees upper than the heart. The neck is extended to set the malar eminence as the highest point in the operative field; this helps gravity-related retraction of the frontal lobe. A linear incision is made in the right eyebrow, while caring for the supra-orbital artery and nerve. The frontalis muscle is incised parallel to the skin incision and retracted by stay sutures. By placing two side by side burr holes (1 inch apart) in the supraciliary area, and ellipsoid craniotomy is performed (Figure 1), and the dura is opened in a linear fashion. At this point, the operating microscope is brought into the field and a small brain spatula is used to retract the frontal lobe off the orbital roof. Cerebrospinal fluid aspiration via a previously placed ventriculostomy (if present) catheter greatly aids in safe and effective frontal lobe retraction. As soon as the right optic nerve and right carotid artery are identified, the arachnoid of the optic and carotid cisterns is opened to allow more CSF to egress. Then, attention is directed toward the inter-optic space and the optic chiasm. Passing a few millimeters back over the optic chiasm leads the surgeon to a thin translucent gray lamina which forms the anterior wall of the third ventricle (i.e. Lamina Terminalis). This lamina is fenestrated widely with the help of microscopic hook and dissector, such that the lateral walls of the third ventricle are clearly visualized. In previously established cases of hydrocephalus, the lamina terminalis is wider and thinner than normal and bombed toward the surgeon, and therefore its identification and fenestration is easier. Care must be taken not to injure the arterial structures (i.e. the ACA-ACoA complex).

After opening the LT, one could see the free gush of CSF through the fenestration. It is important to avoid traumatic hemorrhages while approaching the site of LT, because any blood in CSF space could have a deleterious effect on the result of surgery. The retractor is taken off the field and the dura is closed in water-tight fashion and craniotomy is closed without placing a drain in place. In cases that the frontal sinus wall is violated it should be closed and packed to prevent CSF leak. However, attention to the preoperative images could avoid this complication by placing the craniotomy a little more laterally to avoid breaching the frontal sinus.

\section{RESULTS}

All patients improved in terms of clinical signs and symptoms such as, headache, dizziness, diplopia, papilledema, etc., and/or radiological evidence of hydrocephalus within few days of surgery (Figure 2A,B). There was one case of Chiari I malformation and hydrocephalus whose symptoms of long tracts and syringomyelia started to improve following the operation for LT fenestration. 

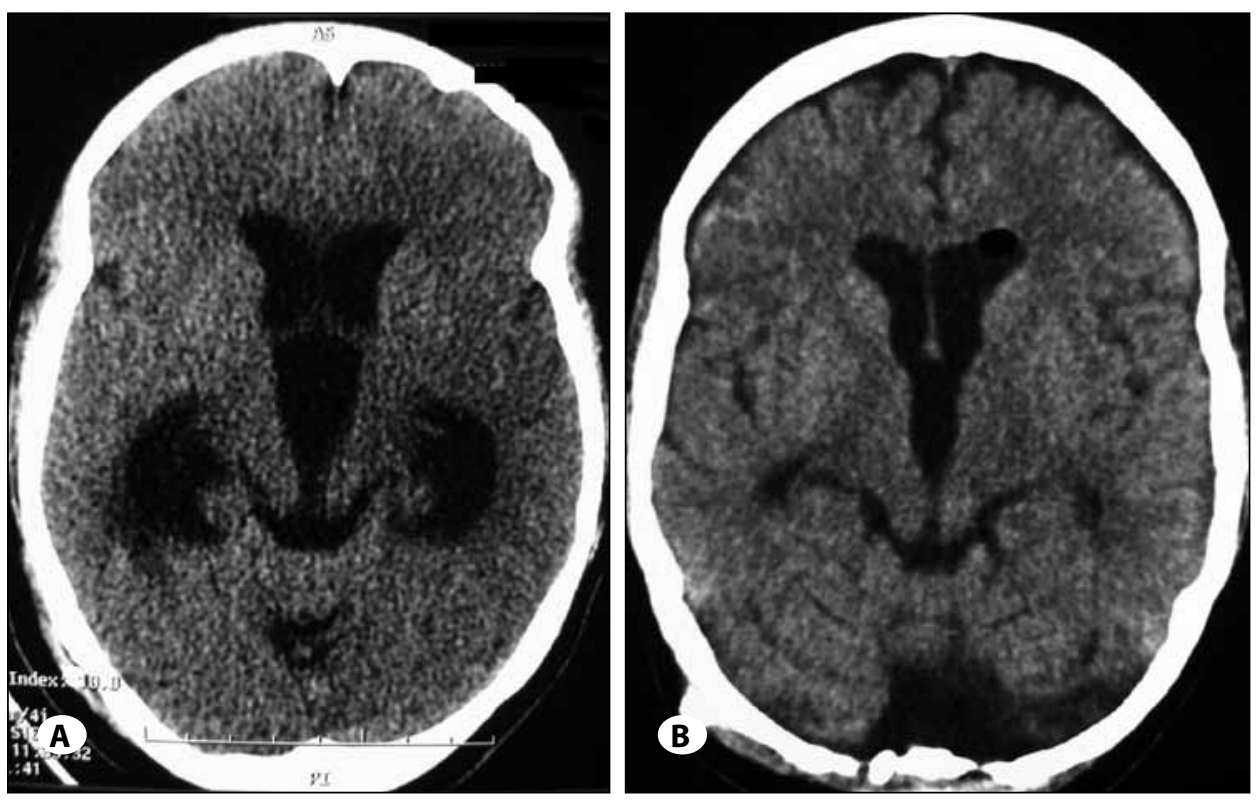

Figure 2: Brain computed tomography of a patient with hydrocephalus before (A) and after terminal laminotomy (B).

Neither postoperative intracerebral and intraventricular hemorrhage occurred; nor did patients need a second surgery for CSF diversion. All patients had uneventful post-operative course.

In a 6-month follow-up period no recurrence was observed due to re-stenosis of the opening.

\section{DISCUSSION}

Treatment of hydrocephalus is still a major challenge to neurosurgeons. With shunting procedures, we face the burden of malfunction, infection, shunt dependency, over-shunting and other complications. This has caused other treatment modalities to be devised in which foreign bodies are not implanted in the body. Endoscopic third ventriculostomy, first introduced by Guiot in 1970s (12) is reported to be safe and effective (14). It is especially advantageous in two aspects: (1) the avoidance of foreign body implantation and (2) the establishment of a "physiological" CSF circulation (9).

\section{Why try to find an alternative to ETV?}

The technique of ETV has its own drawbacks, however. Injury to the basilar artery or to its branches (i.e., the vessels present in the interpeduncular cistern), although rare, is an extremely severe complication of ETV. It has a prevalence of $1 \%(9)$. This risk is escalated when the floor is thick/opaque due to acute hydrocephalus or previous diseases such as infection (9). Furthermore, slit ventricles in cases of shunt malfunction might make a standard ETV impossible (17).

The anatomical structures most commonly damaged during ETV are the walls of the $3^{\text {rd }}$ ventricle and those delimiting the foramen of Monro (9). Short-term complications are usually due to silent contusions of the thalamus, fornix, or the mammillary bodies secondary to the incorrect manipulation of the ventriculoscope and/or instruments $(9,21)$. This risk is increased in cases of anatomical variations which are relatively common in infants. Impairment of short-term memory (4), non-focal neurological deficits such as confusion and impairment of consciousness $(2,9)$, post-herniation syndrome (3), "aggressive behavior" and "disinhibition" due to frontal lobe injury $(4,9)$, hemiparesis (5), and other complications have been reported as the neurological complications of the procedure.

Complications (transient bradycardia and other intra-operative cardiac complications) due to hypothalamic damage are not uncommon in ETV and are reported to be direct side-effects of the endoscopic technique within the $3^{\text {rd }}$ ventricle (9).

Subdural fluid collections after ETV are reported to have a prevalence of $0.5-1.5 \%$ in large series (21) which some believe to be even underestimated $(9,24)$ especially in infants with immature absorptive mechanisms which favor the escape of CSF through the cortical tract of the ventriculostomy into the subdural space.

Intraventricular hemorrhage is the most common complication of ETV that might prevent performing a safe ventriculostomy in which case the procedure should be terminated $(6,9)$. This problem might be more common in infants because of unfavorable anatomy (smaller foramen of Monro, larger interthalamic adhesions) (9).

\section{Why Lamina Terminalis?}

Lamina terminalis, forming the anterior wall of the $3^{\text {rd }}$ ventricle is intimately related to the basal cisterns, and its fenestration, can be a conceptually logical means of $3^{\text {rd }}$ ventriculostomy as an alternative to $\operatorname{ETV}(17,22)$. Other reasons include: (1) the LT constitutes a clearly identifiable microsurgical target, (2) minimal amount of retraction is needed to expose the LT and there is generally no need to mobilize the ACA-ACoA complex, (3) perforating branches to 
the hypothalamus and optic apparatus do not interfere with LT fenestration in most cases (8), (4) fenestration of LT is a safe procedure, provided that the relevant anatomic landmarks are identified, and (5) most importantly, the allowable extent of LT opening is sufficient to provide wide access into and free CSF flow from the $3^{\text {rd }}$ ventricle (8).

Moreover, it has to be noted that during ETV, the surgeon faces the membrane to be incised (i.e., floor of the $3^{\text {rd }}$ ventricle) prior to the visualization of the vessels in danger, while in the described technique of microsurgical fenestration of the LT, the surgeon first encounters the vascular structures to be protected and then the membrane to be incised which theoretically decreases the inherent hazard of vascular injury present in ETV (16). It has also been said that in certain circumstances such as in patients with low-grade gliomas of the midbrain and pons, fenestration of the LT might seem superior to ETV since a blockage of the CSF circulation by narrowing of the prepontine space including the site of ETV, might be avoided for a longer time period (17).

The lamina terminalis, a thin transparent whitish membrane of gray matter, forms most of the anterior wall of the third ventricle $(8,10,19)$. The length of lamina terminalis (distance between the anterior commissure and the optic chiasm) is reported to be averagely $8.25-9.75 \mathrm{~mm}$ (range 6-17.5mm) (8, 10) comprising a generous surface area of about $52 \mathrm{~mm}^{2}$ to be fenestrated (8). Fenestration of the lamina terminalis is not a new microsurgical technique. Microscopic $3^{\text {rd }}$ ventriculostomy via opening of the lamina terminalis was first introduced by Dandy in 1922 (his proposed technique required sacrifice of one optic nerve and bore a mortality rate of 15\%) (7). Later on, Scarff reported a treatment method for hydrocephalus by puncture of the LT ( \pm floor of the $3^{\text {rd }}$ ventricle) (20). The technique of $3^{\text {rd }}$ ventriculostomy, after its hibernation during the "shunting era", was revived in the form of ETV. It seems that we are facing the resurgence of the technique of fenestration of LT as in the management of subarachnoid hemorrhage $(1,25)$.

Access to the LT cistern is easily provided by a subfrontal microscopic approach through a supra-ciliary craniotomy. Also, endoscopic subfrontal approach to this area has been described in a cadaveric study (23). This approach would also facilitate the opening of chiasmatic and carotid cisterns along with the LT cistern which helps the diversion of CSF from the $3^{\text {rd }}$ ventricle to the basal cisterns.

\section{Caveats and Complications}

Reisch et al have nicely listed some important "tips and tricks" to facilitate the supra-ciliary "key-hole" craniotomy and maximize the access to the cerebral basal structures to which the reader is referred (18).

In one of our cases, the access to the lamina terminalis was difficult due to a high slope of the floor of the anterior fossa. Coarse undulations of the orbital roof can obscure the angle of access to the chiasmatic region. We believe, however, that proper positioning of the patient will nearly eliminate this problem and drilling of the orbital roof will not be necessary to increase exposure of the central skull base in most cases.

We think that this approach is not suitable for patients with large frontal sinuses which could be entered during craniotomy and cause CSF leak and related complications.

It has been said that this approach needs the opening of the Liliequist's membrane as a necessary step (25). Contrary to this view, along with Akyuz et al (1) we think that this step is not essential as we did not open this membrane in the present series and observed the favorable end results in our patients.

\section{CONCLUSION}

We report eight cases of microscopic third ventriculocisternostomy via a supraciliary subfrontal craniotomy and LT fenestration for the treatment of hydrocephalus, with satisfactory results. We think that this technique has some advantages: (1) no need to traverse neural tissue and hence less neurological complications than ETV, (2) no need to endoscopic equipment and the demands of the endoscopic technique, (3) less risk of vascular injury and hypothalamic damage compared to ETV, and (4) effective treatment of hydrocephalus. However more sample size is necessary to attribute good results to this alternative approach to ETV.

\section{DISCLOSURE}

The authors report no conflict of interest concerning the materials or methods used in this study or the findings specified in this paper.

\section{ABBREVIATIONS}

ACA: Anterior cerebral artery

ACoA: Anterior communicating artery

CSF: Cerebrospinal fluid

ETV: Endoscopic third ventriculostomy

LT: Lamina terminalis

MTV: Microsurgical third ventriculocisternostomy

\section{REFERENCES}

1. Akyuz $M$, Tuncer $R$ : The effects of fenestration of the interpeduncular cistern membrane arousted to the opening of lamina terminalis in patients with ruptured ACoA aneurysms: A prospective, comparative. Acta Neurochir (Wien) 148:725-732, 2006

2. Baskin JJ, Manwaring $\mathrm{KH}$, Rekate $\mathrm{HL}$ : Ventricular shunt removal: The ultimate treatment of the slit ventricle syndrome. J Neurosurg 88:478-484, 1998

3. Beems T, Grotenhuis JA: Long-term complications and definition of failure of neuroendoscopic procedures. Childs Nerv Syst 20:868-877, 2004

4. Benabarre A, Ibáñez J, Boget T, Obiols J, Martínez-Aran A, Vieta E: Neuropsychological and psychiatric complications in endoscopic third ventriculostomy: A clinical case report. J Neurol Neurosurg Psychiatry 71:268-271, 2001 
5. Brockmeyer D, Abtin K, Carey L, Walker ML: Endoscopic third ventriculostomy: An outcome analysis. Pediatr Neurosurg 28:236-240, 1998

6. Buxton N, Macarthur D, MAllucci C, Punt J, Vloeberghs M: Neuroendoscopy in the premature population. Childs Nerv Syst 14:649-652, 1998

7. Dandy W: Treatment of non-encapsulated brain tumors by extensive resection of contiguous brain tissue. IV an operative procedure for hydrocephalus. Johns Hopkins Hosp Bull 33:189-190, 1922

8. De Divitiis O, Angileri FF, d'Avella D, Tschabitscher $M$, Tomasello F: Microsurgical anatomic features of lamina terminalis. Neurosurgery 50:563-570, 2002

9. Di Rocco C, Massimi L, Tamburrini G: Shunts vs endoscopic third ventriculostomy in infants: Are there different types and/or rates of complications? A review. Childs Nerv Syst 22:1573-1589, 2006

10. Erturk M, Kayalioglu G, Ozer MA: Morphometry of the anterior third ventricle region as a guide for the subfrontal (translaminaterminalis) approach. Neurosurg Rev 26: 249-252, 2003

11. Gangemi $M$, Donati $P$, Maiuri F, Longatti $P$, Godano U, Mascari C: Endoscopic third ventriculostomy for hydrocephalus. Minim Invasive Neurosurg 42:128-132, 1999

12. Guiot G: Ventriculo-cisternostomy for stenosis of the aqueduct of Sylvius. Puncture of the floor of the third ventricle with a leucotome under television control. Acta Neurochir (Wien) 28:275-289, 1973

13. Jallo Gl, Kothbauer KF, Abbott IR: Endoscopic third ventriculostomy. Neurosurg Focus 19:E11, 2005

14. Jones RF, Kwok BC, Stening WA, Vonau M: The current status of endoscopic third ventriculostomy in the management of non-communicating hydrocephalus (Abstract). Minim Invasive Neurosurg 37:28-36, 1994
15. Lifshutz Jl, Johnson WD: History of hydrocephalus and its treatments. Neurosurg Focus 11(2): Article 1, 2001

16. Oertel J: Response to "Anterior third ventriculostomy: An endoscopic variation on a theme. J Neurosurg 113:1260, 2010, published online August 13, 2010; DOI: 10.3171/2009.11. JNS091698

17. Oertel JM, Vulcu S, Schroeder HW, Konerding MA, Wagner W, Gaab MR: Endoscopic transventricular third ventriculostomy through the lamina terminalis. J Neurosurg 113:1261-1269, 2010

18. Reisch R, Perneczky A, Filippi R: Surgical technique of the supraorbital key-hole craniotomy. Surg Neurol 59:223-227, 2003

19. Rhoton AL Jr: The lateral and third ventricles. Neurosurgery 51 (Suppl 1):S1-S207, 2002

20. Scarff JE: Treatment of obstructive hydrocephalus by puncture of the lamina terminalis and floor of the third ventricle J Neurosurg 8:204-213, 1951

21. Schroeder HWS, Niendorf WR, Gaab MR: Complications of endoscopic third ventriculostomy. J Neurosurg 96: 1032-1040, 2002

22. Souweidane MM: Anterior third ventriculostomy: An endoscopic variation on a theme. J Neurosurg 113: 1259-1260, 2010

23. Spena G, Fasel J, de Tribolet N, Radovanovic I: Subfrontal endoscopic fenestration of lamina terminalis: An anatomical study. Minim Invas Neurosurg 51:319-323, 2008

24. Teo C: Complications of endoscopic third ventriculostomy. In: Cinalli G, Maixner WJ, Sainte-Rose C (eds), Pediatric Hydrocephalus. Springer, Berlin Heidelberg New York, 411-420

25. Van Lindert EJ: Microsurgical third ventriculocisternostomy as an alternative to ETV: Report of two cases. Childs Nerv Syst 24:757-761, 2008 